\title{
Māori-language newspapers 1842- 1945: A survey, with a focus on the expression of oral tikanga on the page
}

\begin{abstract}
This paper canvasses Māori-language print media from the first monolingual newspaper in te reo Māori (the Māori language) in 1842 to what is believed to be the last, in 1945. It sets the publications in their social contexts and, importantly, discusses the ways in which the customs of oral culture transferred to the page. Also traversed are the ways in which the arrival of the telegraph and the development of journalistic conventions in the late 1800 s changed the style of Māorilanguage news writing. Links go to digitised copies of the 18 th century newspapers and credible, related sources of information. ${ }^{1}$
\end{abstract}

\footnotetext{
1 The Māori Niupepa Collection comprises more than 17,000 pages taken from 34 separate periodicals, published primarily for a Māori audience, between 1842 and 1932. A total of $70 \%$ are solely in Māori, $27 \%$ are bilingual and 3\% are in English. Microfilm held by the New Zealand National Library Te Puna Mātauranga o Aotearoa was digitised by staff of the New Zealand Digital Library (NZDL), which is part of the Computer Science Department, University of Waikato. The writer sends a piki mihi (big thank-you) to its staff for the valuable work they have done to make our printed taonga available. Many links in this article go to the pages of publications that have been digitised. All other images and extracts in this paper have been reproduced unchanged and with permission. Embedded newspaper pages are high resolution so they can be enlarged and read.
} 


\section{Introduction: Reading, writing and Māori}

Before the arrival of missionaries and settlers, the primary way to transmit information between and within iwi (tribes) was whaikōrero, or formal oratory. As Rewi noted in his book Whaikōrero (2010), oratory:

helped people make decisions with regard to all matters affecting their living arrangements, their work, and their daily, monthly and yearly activities that would keep them safe. If there were any major issues to put before the people, each speaker would stand and air their opinion until all concerned had expressed what they had to say (p. 14).

Speakers built on each other's commentary, like a news story laying out points of view. Then, as now, speakers followed a structure and called on cultural knowledge to frame the 'news', using chants, allusions and stock phrases, drawing on imagination and wit, and often making references to whakapapa (genealogy) and people and places important to listeners (Rewi, 2010).

The arrival of British explorer James Cook and the Endeavour at Tūranganui (Poverty Bay) in 1769 is, perhaps, where the whakapapa of Māori writing began. Three boys from the Rongowhakaata iwi were captured and taken on board. Travelling with Cook was the Tahitian high priest Tupaia, who was able to use his native tongue, which is related to te reo Māori, to talk with the boys. They spoke their names to Cook's scientist Joseph Banks, who wrote them (Jones \& Jenkins, 2011).

In the early 1800 s, newly arrived missionaries spurred the development of a reo-Māori orthography, translated the Bible into Māori and used it to teach their converts to read and write in te reo. The first school for Māori children was set up by Anglicans in 1816 (Biggs, 1968). McKay (1940) wrote that:

The missionaries were surprised and gratified at the eagerness of the Maori in their desire to learn to read and write, and their facility in learning ... the merest children 
and grey-haired men were equally eager; and if they were not equally facile, the older made up in persistence what they had lost with the plasticity and adaptability of youth (p. 34).

The newly literate often returned to their kāinga (settlements) to teach others (Anderson et al., 2014; Mikaere $\&$ Head, 1988). There are no reliable indications of the numbers of Māori who were able to read and write te reo at that time (Maslen et al., 1997), but Mikaere \& Head (1988) have provided a useful summation of the theories. For example, Parr (1963) claimed that by the 1850 s, about half of the adult Māori population could read Māori and about one-third could both read and write in te reo. Indeed, Māori may even have been more literate in their native language than British settlers (Biggs, 1968). Whatever the true figure, we know that literate Maori employed these skills with great gusto in their social and political lives - and particularly in an important English import, the newspaper (Jones \& Jenkins, 2011; Maslen et al., 1997; McRae, 1983).

\section{Papers of the colonial era}

From the 1840 s to the early 1930 s, more than 40 reoMāori newspapers debated ideas, reported news, advertised goods and services and generally recorded Māori life, traditions, opinions and language use (McRae, 2014).

Māori-language newspapers were produced by four broad groups: The Government; churches; private businessmen - these three groups all Pākehā-led - and iwi groupings, the latter's papers set up to protest Government encroachment (Curnow, 2002). However, all the papers, regardless of whomever was in charge, "acted quite transparently as propaganda organs with political, religious and cultural agenda" (Paterson, 2002, pp. 7980 ), and were often opinionated and contentious (Curnow et al., 2006). Newspapers were tools for people with money and ideological agendas; journalism was yet to 
reinvent itself as a neutral purveyor of public information (Schudson, 2011).

Still, Māori were keen on the papers as they leavened a diet of religious literature (Paterson, 2004). It was common for one person to read aloud an entire newspaper to a circle of attentive listeners, after which discussion would ensue:

By publicly reading the newspapers and discussing them, a consensus of meaning and agreement in decisionmaking could be reached, as would be expected given the nature of Māori tribal society. This is also evident in letters printed in the newspaper, many with large numbers of names appended to them. The individual who actually put pen to paper would have possessed good writing skills, yet may have merely been an anonymous scribe (Paterson, 2004, p. 39).

\section{Government newspapers}

The colonial Government was quick to exploit the power of print (Rogers, 1998). The first Māori-language newspaper was the monthly Ko te Karere o Nui Tireni, (The Messenger of New Zealand, January 1842-January 1846), ${ }^{2}$ produced at the command of the country's first Governor, William Hobson. The first paragraph in the new paper stated that it had been started "so Māori understand the laws and customs of the Pākehā and Pākehā also understand Māori ways". The following paragraphs made clear the Government's assimilationist agenda: The paper's focus would be "first, the Governor's decrees and secondly the Queen's laws; the means of applying justice and the crimes for which people are tried, and a great deal concerning Pakeha customs" (Curnow et

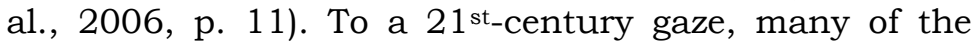

\footnotetext{
2 The first English-language newspaper had come out two years earlier. The New Zealand Gazette, published from August 21, 1839 to September 25, 1844, was the mouthpiece of the New Zealand Company, a private enterprise that "sought to establish a Better Britain' or 'Britain of the South', in which English class distinctions were preserved" (King, 2003, p. 172).
} 
articles are "condescending, even offensive" (Paterson, 2016 , p. 48). This first paper, which ran to 49 issues, underwent several iterations as its publisher's ideology against Māori hardened (Paterson, 2004; 2016).

Other Government papers included Te Waka Maori o Ahuriri (The Māori Canoe of Ahuriri]) a fortnightly produced in Napier between 1863 and 1871. It was succeeded by Te Waka Maori o Nui Tireni (The Māori Canoe of New Zealand), a monthly produced in Wellington 1871-1877. These papers also pushed the Government's agenda to assimilate Māori politically, socially and economically (Paterson, 2002), but that didn't mean Māori voices were silenced: Māori were keen correspondents, and their voices in the papers will be explored soon.

\section{Church newspapers}

Church-based newspapers aimed at Māori urged readers to keep the faith and promoted temperance and the value of European ways. The first Māori-language church newspaper was the Wesleyan Te Haeata (The Dawn Streaks of Light), which ran to 37 issues between 1859 and 1861 . It was typical of its breed:

Highly didactic - often using Māori proverbs and metaphors in support of its lessons - much of the paper was given over to exhorting Māori to keep the faith, abandon their customary beliefs, and live and be educated as the Pākehā. The reporting on local and overseas news and political matters - the King Movement, war in Taranaki and trouble in Waikato - is conservative, and contributions from Māori are primarily in support of the church and faith (McRae, 2014, p. 3).

The Māori clergy of the Church of England living on the East Coast established a noteworthy press, putting out He Kupu Whakamarama (Words of Enlightenment, 1898-1902); Te Pipiwharauroa (The Shining Cuckoo, 1899-1913); Te Kopara (The Bell Bird, 1913-1921); and Te Toa Takitini (The Legion, 1921-1932) (McRae, 2014). 
In 1924, the syncretic religious movement Rătana, led by faith healer and prophet Tahupōtiki Wiremu Rātana, began publishing a general newspaper in Māori, Te Whetu Marama o te Kotahitanga (The Shining Star of Unity). However, over time, a greater proportion of stories appeared in English and the newspaper's focus narrowed to church matters (Curnow, 2002); the paper is published still. The Presbyterian Church published Waka Karaitiana (The Christian Canoe, 1933-96), covering church news, the faith and social and political matters (McRae, 2014).

\section{Private papers}

Several wealthy Pākehā published newspapers in the late 1840 s and 1850 s, driven their desire to improve Māori society through Christian living. One was Charles Davis, an interpreter with a "genuine liking for Māori" (Curnow, 2002, p. 20) who had previously been involved with Government papers. He published three short-lived papers, Te Waka o te Iwi (The Tribes' Canoe) which ran to two or three issues from October 1857; Te Whetu o te Tau (The Star of the Year) (June, July and September 1858); and the bilingual Ko Aotearoa or the Maori Recorder (January 1861 and January 1862) (Curnow, 2002, p. 20). Later on, W.P. Snow, a "pious and benevolent American gentleman of means" (Hocken, 1909, p. 545) set up the monthly newspaper Te Korimako (The Bell Bird), (18821888) and appointed Davis as editor (Curnow, 2002).

The lines between private and state papers did blur unsurprisingly, given their common cause of 'civilising' Māori. A young Native Department official, Walter Buller, who had already been involved in government publishing, set up Te Karere o Poneke (The Wellington Messenger) (1857-58), which, despite the government coat-of-arms in the masthead, was a private enterprise by Buller and his missionary father (Paterson, 2004). The paper was particularly active in promoting "ngā ritenga pai o te Pākehā", or the law, religion and habits of the settlers, and attracted many letters from Māori on these subjects 
(Paterson, 2004). The government provided grants to Te Karere o Poneke, which had been set up by Hawke's Bay bureaucrat Donald McLean (Paterson, 2004). The government in 1871 took it over, renaming it Te Waka o Niu Tirani (The Waka of New Zealand) (1871-1879) (Paterson, 2004).

It is tempting, when looking back at the collective power of the $19^{\text {th }}$ century newspapers through a postcolonial lens, to see collusion between the Pākehā-run papers and the Crown to promote Māori deculturation. However, there is no evidence of such an agenda; they simply shared the belief that Māori would do better if they behaved more like Pākehā, and their newspapers echoed that conviction (Paterson, 2002).

\section{Māori-owned newspapers}

Papers run by Māori, in Māori and for Māori flourished from the 1860s. Their main concern was amplifying iwi concerns about government activities and policy. $\underline{\mathrm{Te}}$ Hokioi o Niu Tireni e Rere atu na (The War-bird of New Zealand That Flies Out), (1861-1863), was the first Māoriowned and Māori-run paper wholly in te reo. The hōkioi was a bird "whose cry, heard only at night, was an omen of war" (McKay, 1940, p. 41). The monthly paper was also "the first and most radical example of indigenous media activism in New Zealand" (Paterson, 2013, p. 124). It was founded and controlled by the Kingitanga movement, the Waikato-based confederation of North Island tribes that united to resist Government encroachment.

The paper's sole aim was advancing the interests of the Kingitanga, whose monarch at the time was the second king, Tāwhiao. The message to the Crown was blunt: We will not cede land or independence (Paterson, 2006). The paper was edited by Wiremu Pātara Te Tuhi, an advisor to the king whose "articles were full of native wit and ability" (McKay, 1940, p. 42). As well as reporting Kingitanga business, the paper, which appeared irregularly but least 10 times, ran letters containing local news and opinion, the words of waiata (songs) and reports 
from overseas (McKay, 1940; Niupepa: Māori Newspapers, n.d.).

Aware that Te Hokioi would galvanise Māori against the government, Governor George Grey ordered the establishment of a paper to counteract it, a task effected by the Crown's local magistrate, John Eldon Gorst, in February 1863. Gorst named the paper Te Pihoihoi Mokemoke $i$ runga $i$ te Tuanui, which was translated as The sparrow alone upon the roof. ${ }^{3}$ The "two birds" sparred vigorously for several months until Ngāti Maniapoto chief Rewi Maniapoto sent his warriors to Te Pihoihoi to shut it down (Paterson, 2006; Weir, 1947). On July 12, 1863, on a flimsy pretext, government troops invaded Waikato (King, 2003).

Further south, there was rising concern among Māori about dubious land sales to settlers. Several notable papers were published by the Hawke's Bay-based Repudiation movement, which wanted such sales disavowed on the grounds of fraud. Among the papers was Te Wananga (The Forum), which ran from 1874-78. Initially monolingual but later bilingual, it focused on issues around land and Māori representation, as well as carrying overseas news, items from other papers, reports of tribal meetings, customs, traditional history, genealogies and songs, parliamentary news, bills and election results (Curnow, 2002; Waymouth, 2002).

The Kīngitanga, still directed by Tāwhiao, started a second newspaper, Te Paki o Matariki, in 1891. It was monolingual, directed at Kīngitanga supporters and appeared several times a year in its early days. The paper's content ranged from notices, reports of hui and records of discussions with the Government to addresses by the king (McKay, 1940). Te Paki o Matariki means the fine weather of Matariki and refers to the calm weather heralded by the appearance of the Matariki star cluster

\footnotetext{
3 This is a reference to Psalm 102:7 of the Bible: "I watch, and am as a sparrow alone upon the housetop." However, the word pīhoihoi was mistranslated - it names the New Zealand lark or pipit, Anthus novaeseelandiae (Weir, 1947; Williams, 1971).
} 
(Pleiades) in the sky at the start of spring: "This weather, and in this case the newspaper, symbolise the optimism of the beginning of a new season or new age" (Papers Past, n.d.).

The coat-of-arms of the Kingitanga is also named Te Paki o Matariki and dominates the masthead. Its design refers to the stars of Matariki and the creation of the world and features figures denoting Aituā (misfortune) and Te Atuatanga (spirituality). A Christian cross is included (Royal, 2017). In issue 6, the paper became bilingual for several issues to apparently cater for the paper's "European friends", but several issues later reverted to Māori. The paper ran intermittently, with gaps of several years between some editions, until 1935 .

June 1892 saw the publication of just two issues of a reo-Maori newspaper titled Aotearoa. Its backers, JG Taiaroa, Te Kani Pekai, Arapata Karaitiana and Wiremu Muhunga Porotene, were all sons of important chiefs (Curnow, 2002). The paper was aimed exclusively at Māori, with first issue explicitly stating that no Pākehā had any role in the paper's production. Aotearoa covered parliamentary proceedings, meeting and Land Court business. However, as was often the case with newspapers of the era, a lack of advertising led to its collapse (Curnow et al., 2002).

Concerned about land law that disadvantaged Māori, and mistrustful of the Pākehā-run national parliament, various tribes established Te Kotahitanga, a Māori Parliament, to seek constitutional authority of their own. Hastings-printed Huia Tangata Kotahi (Unite the people) was the first of several newspapers published under the Kotahitanga umbrella. Published from 1893 to 1895 , Huia Tangata Kotahi carried coverage of the Māori Parliament's proceedings, letters and notices, local and foreign news and advertisements (Curnow et al., 2002).

A successor was the monthly paper Te Puke ki Hikurangi (The Hill at Hikurangi), producing more than 180 issues in the periods 1897-1900; 1901-06; and 1911-1913. It covered a wide range of issues and was 
notable for the involvement of a woman who emerged as a major force in the Māori-language newspapers: Niniwai-te-rangi, also known as Niniwa Heremaia. She chose and translated items from English-language newspapers for the paper and wrote numerous reports (Curnow, 2002).

Coalitions of Māori also produced newspapers. One, involving 25 elderly men, was The Jubilee Te Tiupiri (1898-1900), a bilingual and highly loyalist paper that commemorated Queen Victoria's 1897 Jubilee and ran to more than 70 issues. The first story in its first edition lists the reigns of the entire British monarchy from 1066. The same story also describes the "great European nation" as having "constant mana and chieftainship", while the Māori were "still in darkness, living through the want of energy in our dealings; for this reason, we, the elderly gentlemen belonging to this place set about establishing a newspaper". These elderly gentlemen were aware that it was common for one person to buy a newspaper and then read it to many; this was clearly bad for business, and that first issue asked purchasers not to read its stories aloud. News content ranged from reports from the Māori and New Zealand Parliaments to local news, traditions, land matters, sport, racing and theatre (Curnow et al., 2002).

\section{Who were the journalists?}

The phrase "citizen journalism" to denote ordinary citizens gathering and spreading the news may appear to be a development of the digital era (Tilley \& Cokley, 2008), but it was thriving in the mid-1800s, with ordinary Māori contributing substantial content to the reo-Māori newspapers of the era (Head, 2002). Newspaper proprietors from the 1840 s to the 1860 s, publishing before the advent of professional journalism and widespread telegraph transmission, faced a small population from which to raise subscriptions, a shortage of advertising, and minimal staffing; they actively encouraged readers to send stories (Curnow et al., 2006). 
For example, a Te Pipiwharauroa editorial on April 1, 1899 , exhorted readers to play journalist:

\section{E nga kai}

whakehaere tukua mai nga korero o koutou na takiwa; nga korero hui, sobi moni, whakaatu mai i te ahua o houtou na whenua, o noa taigata, i o koutou na whakagro ranei, i nga whakatauki ranei a tana a te Maori, me te tini o era atu lorero e tika ana mo ta taton pepa. Kaua e tatari kia wharona rawa te korero ke tuku mai ui. Tukuna mai nge pito-pito korero. Kaua o roa rawa te korero.

Te Pipiwharauroa, April 1, 1899, p. 6

Curnow et al. (2006), translated the above thus:

Organisers, send in reports of your own areas: reports of meetings, money, description of the situation of your lands and of the people, or about your ideas, or sayings of ours, the Maori, and many other reports which are appropriate for our paper. Don't wait until the news is known and then send it in, but send in snippets of news; don't delay with the news (p.19).

Māori responded enthusiastically: "Men, women, the young, the great and the small wrote letters in the spirit of the long-held tradition of kōrero, of talk and debate" (Curnow et al., 2006, p. 32). Māori wrote in all genres editorials, letters, articles, obituaries, reports of meetings and events, advertisements and notices (McRae, 2002). Publication conferred prestige: "Just as chiefs spoke for their hapū [subtribe], so they often wrote on their behalf also. Getting letters to the editor published, in effect as 
an extension of a good whaikōrero performance, meant that the writer acquired mana" (Paterson, 2006, p. 32).

In the early reo-Māori newspapers, men's voices dominate. Paterson's 2004 study of newspapers published between 1855 to 1863 stated that women's voices were not heard: "Men rarely discussed Māori women, except for expressions of concern about their health or morality" (p. 30). However, we must add a caveat: Paterson's sample covered just eight years. In addition, we can't tell how much these women might have influenced debates before pen was put to paper. We do know that in the $1880 \mathrm{~s}$, in areas where women were politically organised and held mana, women of mana like Niniwa-i-te-rangi in Wairarapa at the time of $\mathrm{Te}$ Kotahitanga were visible and sophisticated correspondents (Ballara, 1993).

Reader letters aside, there were no by-lines on news stories in the papers. Local publications followed the practice of the British press, "implicitly demonstrating that it was the authority of the paper that was paramount, not that of an individual author" (Conboy, 2004, p. 126).

The reader may have noticed from the extract above that the colonial papers used no macrons - short lines above a vowel that mark vowel length, which clarifies a word's exact meaning. In the 1800 s, te reo was healthy and fluent speakers knew instinctively where to elongate vowels. Now, in a climate of reo revitalisation where many people learn te reo as a second language, reminders in the form of macrons help preserve the language's integrity. Macrons have been promoted by peak body Te Taura Whiri i Te Reo Māori, The Māori Language Commission, since its establishment in 1987, and their use is now standard (Day, 2017).

\section{Oral tikanga - a unifying force in reo-Māori papers}

A striking feature of all the newspapers is how seamlessly an oral cultural style translates into print (Head, 2002). Newspapers provided a platform for the 
written and oral to "diverge and converge in a hybridising process" (Paterson, 2006, p. 29). Māori often wrote for the early newspapers as if they were speaking in public, complete with the poetic and formulaic language of whaikōrero. To connect with Māori, Pākehā writers for the Government papers often did the same:

Māori brought ... the precedent and observance of performance and their oral arts, and implicitly, sometimes explicitly, the philosophy that underpinned them. The poetic language therefore found a place in the papers and Pākehā were attracted to the use of it (McRae, 2002, p. 44)

Anything that would be said, sung or chanted in public could appear on a newspaper page, including genealogies, songs, sayings, speeches, incantations and narratives. Newspapers were another marae ātea, a community space for views to be shared, debates held, and communal decisions made (Curnow et al., 2006; Kāretu, 2002).

The wit, repartee and wisdom of oratory on the marae are evident everywhere in the Māori-language press, as is the language characteristic of the oral tradition. Letters might begin with an elaborate mihi to the paper or the editors ... or they might have the simple address ' $E$ hoa $m \bar{a}$ ' ${ }^{4}$ or ' $\mathrm{K} i$ te etita.' 5 In the great range of letters throughout the newspapers, the knowledge and genres of the oral tradition find a prominent place. There are, for instance, debates about whakapapa ${ }^{6}$ and tribal traditions; many letters conclude with waiata, ${ }^{7}$ often appropriately adapted to the topic, or incorporate

\footnotetext{
${ }^{4}$ Friends

5 To the editor

6 Genealogy

7 Songs
} 
tauparapara, 8 karakia $^{9}$ or whakapapa (Curnow at al., 2006, p. 34).

A newspaper that ran to 75 issues between 1882 and 1888 provides several good examples Māori oratorical style on the page. The previously mentioned philanthropist W.P. Snow founded Te Korimako (The Bellbird) to promote Christian living. The bird was an astute choice of metaphor, wrote McRae (2002):

Māori admired its song. Its chorus at dawn announced the light of day that, in their thinking and poetry, represented life and success. It was therefore a fitting image for early reports and news, and put the papers in a good light (p. 45).

In its first edition, the editor's welcome was translated to ensure that all readers would understand the paper's mission and its need for income:

Ko te ingoa mo to tatou taonga, ko "Te Korimako Rere Hisere" Ko tenei, ekoro ma, akona mai to tatou Manu Maori, whangainga hoki ki "nga hua 0 te tau" kia kaha ai tana kotete. Kei runga kei te hoka to tatou Manu, lo ana korero anake 0 rere atu ana $\mathrm{ki}$ rau-whenua, $\mathrm{ki}$ rau-iwi ; koia holki e kila atu nei, whakaahurutia tenei mokai, kia puta ai ta tatou mahara, kia ara ai te kauwae o tenei motu, kia tamia iho te kino, kia whakamoiritia ko te pai.
The name for our valuable paper is "The Kormako." And now, oh Sirs, teach this our Maori bird, and feed it with " the fruits of the year," so that it may possess sufficient energy to speak out. Our bird is on the perch; its sentiments only fly away to many lands, and many peoples, hence my request to you is, nourish this bird, by which means we shall enable ourselves to carry out our project-the advancement of this island ; the dethronement of evil, and the ascendancy of good.

Te Korimako, May 1882, p.1.

\footnotetext{
8 Incantations often used to identify a speaker's origins.

9 Incantation or chant; now often used to also refer to Christian prayers.
} 
The paper is likened to a bird winging its way from kāinga (settlement) to kāinga bringing news from all corners but needing "the fruits of the year", or a subscription, from the people in turn; similar metaphors recur in many $19^{\text {th }}$ century papers. In the first issue, a reader who sent subscription money and a congratulatory letter extended the metaphor:

Не Кири тики Маi.

Ki a Te Kormaro.

E HIKA,-Tena koe! Te manu tuatahi nana nei $i$ rere haere te motu nei, rauna noa ona kokonga me ona kurae. E manu tenei ano au te manukanuka nei ki ou taunga mai ki tooku marae, huanoa i whai atu ai au ki etahi manu, e mau tonu, kati, mahue ana $i$ au te pupuhi $i$ te momona kore. Heoi, no konei ka mahara ano au ki tou rerenga mai ki ahau i era ra kua pahure ake nei. Koia ka tukua atu nei ano e au he reta powhiri maku kia rere mai ano koe ki a au, kei manukanuka koe mo taku whakarerenga $i$ a koe i era ra. He penei holki te whakatauki a oku tupuna, "he mahi na Uetahi e holkia." A tenei ka tulkua atu e au nga puakakara hei taki mai mou kia rere mai ki tooku marae. Heoi nga kupu na to Whaiaipo.

Na T. Eruetr Manihera.

Tangotro, Turangante, 
A Message Sent to Us

To Te Korimako

Sir, greetings! The first bird to fly across this land, around all its bends and headlands, $\mathrm{O}$ bird, I am anxious that you land at my residence. I simply thought when I went after some birds, they would be caught forever. Well, in the end, I left off shooting them because they were not plump. But then I remembered your flying out to me in days gone by. And this is why I am again sending you a letter of invitation, so that you will fly again to me and in case you are upset at my abandoning you in those days. A saying of my ancestors goes like this, 'Uetahi's deed will be returned'. ${ }^{10}$ So, I send fragrant seeds to entice you to fly to my residence. That's all I have to say. From your sweetheart

T.ERUETIMĀNIHERA

TANGOIRO, TŪRANGANUI (Curnow et al., 2006, pp. 54$55)$.

Orbell (1996) noted that birds were an endless source of imagery and ideas; "Maori thought about birds a great deal. Often they identified themselves with them" (p.102). The metaphor of the sweetly singing bird bringing news to all people had positive connotations for both Māori and Pākehā. However, for Māori, there was deeper meaning. As McRae (2002) wrote, there are "unmarked signification" in all genres of Māori communication ( $p$. 49), borne out of a shared culture based on a Māori metaphysical world view.

In Māori thought, humans are intrinsically linked to the environment. Birds, fish, insects and plants as well

10 The name Uetahi is probably a typesetting error, as was common in the 1800 s. Reliable sources record "He mahi nā Uetaha, e hokia", or "Uetaha's work will be finished". According to Mead and Grove (2003), Uetaha was a descendant of Porourangi, the eponymous ancestor of Ngāti Porou, and became "the proverbial figure for someone whose work was always completed on time” (p. 93). 
as phenomena such as the moon, mist, wind and rocks, all possess their own life force, or mauri. The land, its moods, its inhabitants and the places where important events have taken place shape Māori thinking and provide endless metaphorical anchors. ${ }^{11}$ Birds could be omens of death or messengers between the living and dead. A bird's song might mark a sacred place where chiefs lay; birdsong at daybreak was often seen as a sign of the triumph of light over darkness (Orbell, 1996).

To illustrate a typical transfer of environment-related figures of speech to the page, we return to W.P. Snow. He saw few editions of his own paper, dying of a fever in 1883, aged 26. His obituary referenced the bird of the masthead and contained typically Māori allusions:

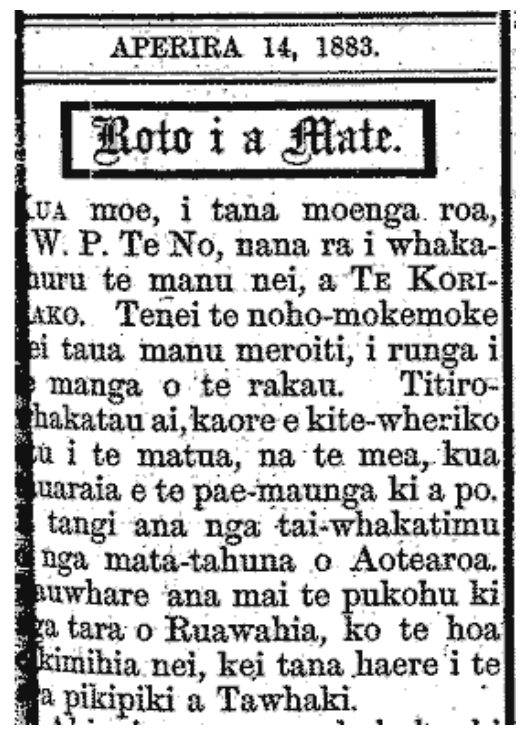

\footnotetext{
11 The advent of Christianity and its allusions didn't subsume Māori metaphor. Māori writers alluded to scripture as well as the tenets of the Māori world, often in the same piece of writing (Kāretu, 2002).
} 
Te Korimako, April 14, 1883, p. 1.

This translation is by Curnow et al., (2006):

W.P. Snow has come to the long sleep of the dead, he who gave the feathers to this bird, Te Korimako. And now the little bird sits lonely on the branch of the tree. Even if looking out intently, he will not see a glimpse of the father, because he has been obscured by the mountain range to Night. The ebbing tides cry against the shores of Aotearoa. Mist hangs over the peaks of Ruawāhia; the friend we seek is on his journey along the path climbed by Tāwhaki (p.193).

The 'long sleep of the dead' is a common sentiment in te reo Māori. The paper is, once again, anthropomorphised as a lonely bird. The feathers reference the pēpeha or saying 'Mā te huruhuru te manu ka rere, mā te kākahu te tangata ka tika ai', which translates as 'By feathers a bird flies and by clothing is a person presentable'. This originally meant to dress appropriately for the circumstances. Like so many Māori expressions, this one found new meaning as times changed. In this context, the feathers are the money with which Snow funded the paper (Mead \& Grove, 2003).

Finally, mountain ranges, raised high and hard to climb, inspired fear and awe. They were often thought to be the homes of spirits and were therefore used as a metaphor for the separation between the living and the dead. It was thought that dying people expired when the tide was ebbing, and outgoing tides were generally associated with misfortune. Mist often signified regret or disappointment (Orbell, 1996). Ruawāhia is one of the domes at Tarawera, near where Snow and his wife lived ('The Late Mr W P Snow', 1883). Tāwhaki is a demigod who climbed to the sky (Reed \& Calman, 2004), so the path climbed by Täwhaki is co-opted as the route to heaven. 


\section{From oratorical to journalistic}

English-language newspapers in the 1800s were turgid; according to Scanlan (2000), "stories were almost always told in the traditional, slow-paced (some might say long-winded) way" (p. 195). Therefore, the oratorical style of Māori-language writing was fitting. But change was coming. Telegraphy, invented in the 1840s, had revolutionised the newspaper business around the world, and, by the last two decades of the century, in Aotearoa as well. News was getting to and around with country in hours, not weeks or months (Scanlan, 2000).

However, telegrams were expensive - senders paid per word. This led reporters to adopt a clipped writing style focused on the new and factual. In his history of Aotearoa's colonial newspapers, Hastings (2013) observed that "such brevity was as far away from the verbosity of the $1840 \mathrm{~s}, 1950 \mathrm{~s}$ and $1860 \mathrm{~s}$ as it was possible to get" (p. 172). It also led to what journalists today term the 'inverted pyramid' news-writing style in which the most important and new information is broadly summarised first, with information of diminishing importance following (Hannis, 2014). Even if readers don't finish the story, they have the most important detail; time-pressed editors can cut quickly from the end.

Māori quickly adopted the journalist's style, wrote McRae (2002). "They incorporated less of the manners and matter of traditional speech and were less rhetorical" (p. 55). More stringent editorial gatekeeping in this era was also an influence:

Newspapers ... sought to appeal by focus on the new. Editors turned down writing which was unclear; cryptic referents to a tribal tradition limited the chance of making a point widely understood (and thereby gaining sympathy); writing had to be explicit for a paper's many readers (McRae, 2002, p. 55).

Oral traditions remained on the page, but were truncated. Songs, sayings, genealogical stories, incantations and stories were still referenced, but 
"journalism, with its European literate conventions, enjoined them to rework those and use others" (McRae, 2002, p. 52).

We have a good example in the below letter to Te Korimako, in which Māori landowners complain about settlers stealing sand. There is just one Māori allusion, to Hawaiki, the ancestral homeland, believed to be in East Polynesia (Anderson et al., 2014). Otherwise, the communication is largely free of ornament:

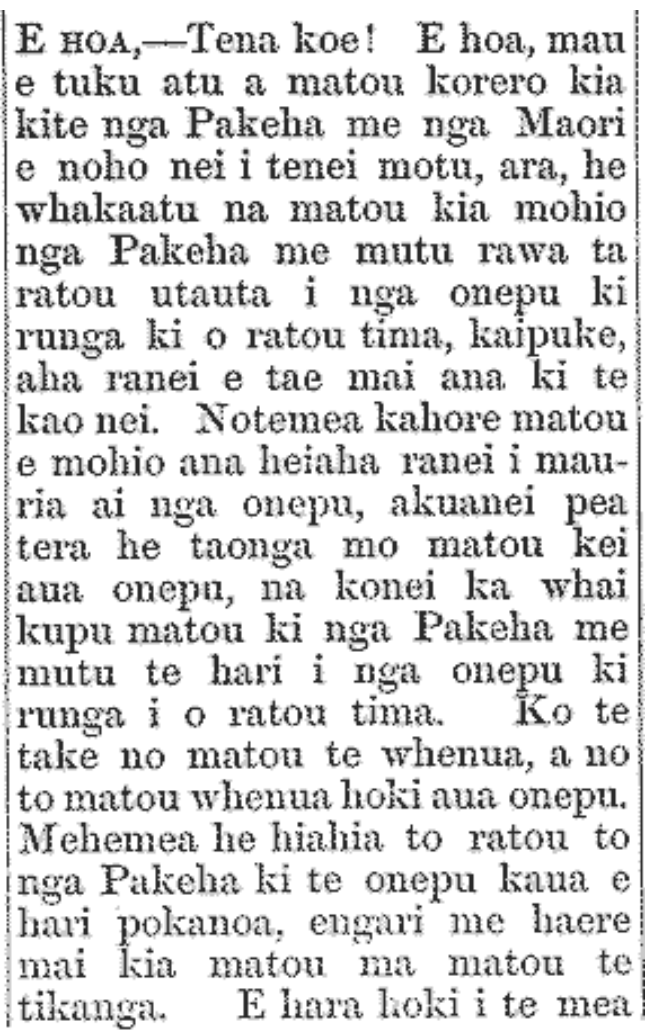


kei Hawaiki matou e noho ana kia hari pokanoa i nga taonga o to matou whenua. E mohio ana. matou ko nga tima o te kamu. pene o te makereka nohoia Akarana, nga tima e auau ana te mahi penei ki nga onepu, heoi he whakamutunga tenei. Kahore o koutou hea $\mathrm{ki}$ tenei whenua e tika ai te max pokanoa. Mehemea he hiahia, kei konei ano matou e noho ana, haere mai pataia.

Te Kao, Pareavgarenga,

Na Eparama Kapa,

" Kezera Horo,

" Hemi Rrumakutu,

"Wiri Te What.

Oketopis, 8, 1884.

Friend, greetings! Friend, you can convey our message for the Pākehā and Māori living in this country to see, that is, to inform the Pākehā that they should refrain from loading sand on to their steamers, boats or whatever, which make their landfall at Te Kao. Because we have no idea as to why the sand is being taken, perhaps there is a livelihood for us in that sand, hence our informing the Pākehā to cease taking sand away on their steamers. The reason is because the land is ours and that sand comes from our land as well. If the Pākehā wish to have the sand they should not merely take it but come to us and we shall decide accordingly. It is not as though we are living in Hawaiki that they should unceremoniously take valuable items from our land. We know that steamers of the McGregor Company of Auckland are the ones taking away the sand on a frequent basis, but this is the last time. You have no shares in this land and therefore no right to take sand without permission. If you so desire, we are here, come and ask. 
Eparaima Kapa, Keepa Horo, Hēmi Riumākutu, Wiki Te Whai.

Te Kao, Pārengarenga, October 8, 1884 (Kāretu, 2002, pp. 9-10).

This writer reads the allusion to Hawaiki to mean that the complainants are witness to the thefts; they are not back in their ancestral homelands and thus unable to see that their sand is being stolen.

\section{The beginning of the end of Māori-language newspapers}

An influx of settlers from the mid-1800s would spell the beginning of the end for reo-Māori publications (Head, 2002). By 1858, the Māori and Pākehā populations had reached parity, at around 59,000 each. After 1874, Māori were less than one-tenth of the total population, and this remained the case for a century (Pool, 2015). Such rapid colonisation was catastrophic for te reo Māori. Anglocentric education policies instituted from the late 1860s tied education funding to English-language instruction and later removed Māori language from the classroom altogether (Biggs, 1968; Ka'ai-Mahuta, 2011; Walker, 2004; Williams, 2001). To gain an education through the Māori-only native schools, children had to board away from home, inhibiting transmission of their parents' tongue and tikanga (culture). This, wrote Marsden, was "cultural genocide" (Royal, 2003, p. 130).

In an environment where English rapidly became the language of public life, the general-interest Māori language newspapers had largely vanished by 1913, apart from religious papers and niche-interest pamphlets (Curnow, 2002). Meanwhile, the English-language press was thriving; by 1911, New Zealand had 64 daily papers for a population of just over a million (Derby, 2014).

There were, however, two reo-Māori papers that tried to swim against the tide of English in the $20^{\text {th }}$ century. The first was Wairere, about which little is known. Two copies have been found, dated February and May 1917; the masthead describes the paper as a weekly. The N.P. 
Kawiti named on the masthead is Nau Paraone, who was, presumably, the publisher. Paraone was a Whangarei boarding-house keeper who stood unsuccessfully for the Northern Maori seat in the 1914 and 1919 general elections (Diamond, 2018).

By this time, editorial cartoons in newspapers were common, and Wairere features them on its front page. The cartoon below shows warriors in waka trying to head off a crocodile which has its mouth open as it heads for the North Island, which is labelled Aotearoa, the word Māori used for the island. The crocodile appears to be named as well, though it's unclear what the word is. Clearly, the animal represents a threat to sovereignty, either national, Māori or both.

We could speculate that the crocodile is a metaphor for a submarine or for Germany. At the time, World War I was raging between the Allies and Germany in Europe, and submarines had already come close to winning the war for Hitler. In January 1917, Germany announced it was reneging on an international code that required merchant ships to be given warning of attack so sailors could escape; from then on, its submarines would shoot and sink. There was fear that the United Kingdom, reliant on food shopped from Aotearoa, would starve and that many merchant seamen would be lost (Keegan, 2000; Lascelles, 2014).

All of the stories underneath the cartoon, whether local or international, concern the war and are written in a clipped journalistic style. Curiously, the first story appears to be fake news: it says that on the Eastern Front, German and Russian troops called a truce so they could work together to eradicate packs of hungry wolves that had become a threat. This story appeared in various newspapers around the world, but the incident has never been verified by Russian sources nor thorough academic work on tallying wolf attacks (Beyond Russia, 2019; Linnell et al., 2002). 


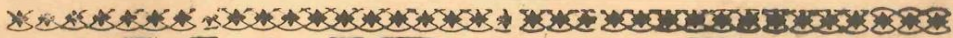 WA
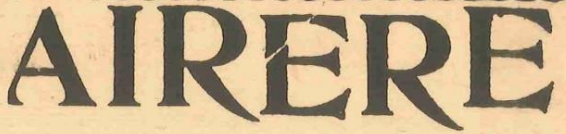

Paralre, Popuere 21917. Kito Tuhi mal N. P. Kawiti Whangaol
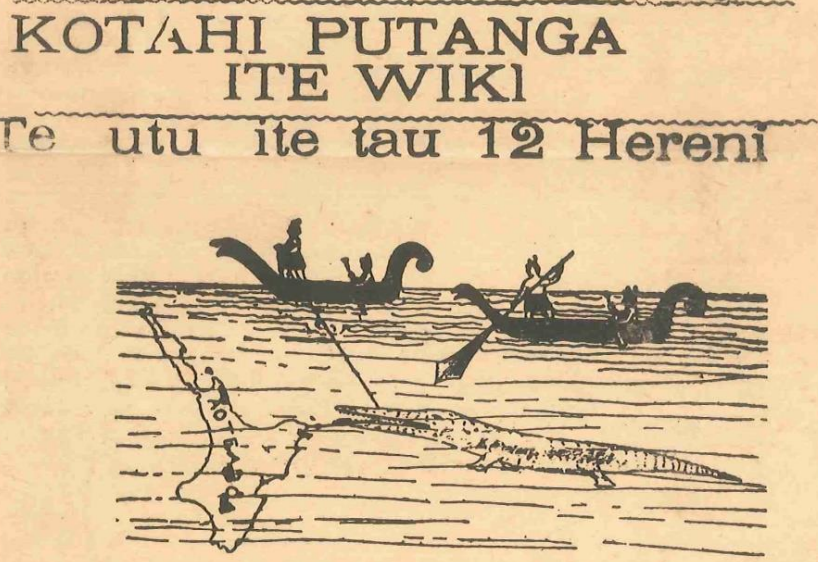

Nga Rongo Korero.

Ite raina whowhai ote tai rawhiti o oropi ara, to wahi kite tlamana raua kote ruhia, he nui te kanul kireho puihi $\theta$ puta ana kl reira i etahi rangi ara te wuruhi, ka mahue inga hola to patu ia ratou ano, ka hurl kite whawhai kinga kararehe to tahi taha, meto tahi taha, kis mutu raka to whawhai kite wuruhi ka hoki tahl mai ratou te ruhia ki tona parepare to tiamana ki tona.

Kote ahua o taraua whawhai etahi waa ka kaha tiamana, peia haere tia te ruhia pau atr re maero a ka kaha ano to ruhia $k a$ siro ano $\theta$ tahi wahi o ratou nohornga, wha whai ana ratou i tenei taima $i$ roto ite wa ote hotoketenga kei aga ho pe to hohonu ki roto ite haupapa.
I roto ite reta a tiamane to Ame rika' keite pal to kie houhis to ro ngo kia perretamu meho mes o wha kaa te Ingtribi kia kaue o haoro acu ma runga 1 taue whenus whe whai atu ai kia ratou.

Kun tao mal te rongo ki whangarei e hoki mai ana takute Frazer-Hurst to rata ote hohipera o whangarei. ko talcuta Wari kua rito mote bo ere kite whawhal, o tabari ana ki hoki mai tera onge rata kl whangarei ki tana hohipera hoki.

I whainatla tetahi pakeho iakarama mo to korero whokapal lis tiamana, ipatal atu otahi wahlne beahs koo to haere al kite whawhal ks mea kia karangetia ka hoere, kamea nga wahine mei kel ti amana kua puhis koo, kemea is pono ano hol to ingirihi ipuhia a Kowbitan ki Airana.

The front page of Wairere, February 1917. Reproduced with the permission of Tāmaki Paenga Hira Auckland War Memorial Museum. 
The second $20^{\text {th }}$ century newspaper of note was run by a woman, Rehutai Maihi of Ngāpuhi (1895-1967). Maihi trained as a compositor before moving into journalism with various newspapers, among them the Englishlanguage Northland Age. In June 1932, with her elders' approval, she launched a general-interest Māorilanguage newspaper, Aotearoa. The paper was unusual, as the only other reo-Mãori papers still in existence at the time were run by churches. In her first issue, Maihi reprinted the Tiriti o Waitangi and invited contributions from readers. Publication was initially weekly but became less frequent and stopped in 1933 (McCallum, 2013).

In following years, Maihi became the first Māori woman to stand for Parliament, as an independent, but was unsuccessful. In September 1940, the second year of World War II, she saw that Māori in New Zealand and soldiers overseas were hungry for information in the reo, so resurrected Aotearoa as a fortnightly, then a monthly (McCallum, 2013). Below is the issue of February 1, 1945. 


\section{A OTEROA}

TE KAKAHU O NGAPUHI

TE REO O TE MOTU

KIA PONO

KIA TOA

KIA MAIA

Te P'utanga Ko te Taite Tratahi o te Marama.

Nga Utu mo te Tau 6/- Ma te Mera $7 / 6$ Mote 3 marama $2 / 6$

Pukapuka 5 Taite, Pepuere $11945 \quad$ Nama 75

O TATOU MATE

E tangi te iwi e trugi lii o taton mate o te kainga nei whiti atu ana ki tawali. Tena kontou tena koutou.

Wiki Tinihau Erueti

He nui te whakatuarea c te iwi i te matenga o Wiki i te Hanuere nei. Haere atn e hine ki o matun kiı Mihi raua ko te lluka oti $\mathrm{ki}$ to iwi nui tonu. Tenn koe e Tini me to whunau. I ngaro ano aia ki Kuikohe tuei.

\section{$\overline{\overline{2}}$}

Trme Wepiha Reo

Tera mate uno ki Krikobe ko Tarme Wepiha lieo i te marama kua huri nei. Kahore ano $\mathrm{i}$ гоa tonas holungs iho $\mathrm{i}$ te whawhai ka mate nei. Te Tauhia tena ra koe me ta korua whanuu.

\section{Marara Paramana}

Tera mate ano no to Hanuere ko Marara Paramana i mate atu ki te hohipere $\mathrm{i}$ te Kawa. kawa ugaro atu ki to Ahuahu.
He Tukolia ki te Pepa

E liara e Puniora Te Arahu, Wharekuri, Chatham Islands, he whakamahara ntu tenei kua tae iho tau huruluara e ahei ai te rere tona ntu o te Aotearua kia koe.

He Tanguta Hei Tango

I Te Tungu : Tokourn

$$
\text { Ratana }
$$

Kun tae tonu mai to ra e pootingia ai he memn hei taugo $i$ te iungu - Tokouru Ratana i te Paramete.

Ko te proti kua tuturu ko te 10 o nga ra o te marama nei

Ko ng» ingoa enei o nga tangutı kun tuturu ka oma a tana ra:

Ko Matiu Rutann o Ratana Pa (Oflicial Labour), Pei te Hurinui Jones ( $\mathrm{I}$ 11. dependent) no Hawera, Kaponga Erueti o Kui Iwi (Ind, Labour), Reha Kau Hou no 'T'e Aroha (Ind), Maharaia Winiata Pinhana o Tauranga (Ind), Tukumara Roretana Yирева o Katikati (Maori People's Labour), Pepiriri liewaţi o Tatranga (Ind), Rehe Parane Rewi Maniapoto Awohrnga o Hangatiki Independent.

Ina risia te kahore kotahi ano te nohonga nei kotahi ano te tangata $e$ tu ko wai ra ki tau whakanro? Kaati rahoki.

Te Kotahitanga Kua Tae Tona $\mathrm{KiTe}$ Pa o Hitara

Ae ko te rongo nui rawa tenei o te wiki nei. Iti iho $\mathrm{i}$ te 50 muero to tawhiti atu o te Kotahitungra $i$ Borlin iti rawa atu kua tae marire atu. Oti ra boli ahalroa kihai i tino tawhiti he nui te tangita e mute o nga talia e rui ka tuhi ano ka tutuki.

Tena ano aianei nga mahi kino a Hitara me ona hoa i mua atu o te pupitiorotanga o tona pa me te lingitanga o te ao kntob kus tuturu nei kna kore e riro iaia.

Tena rawa e Ruhia tino natiuatia atu tena Hitara me ora hoa tautolso katoa. Ahikoa ng i kaumatua mau tolio o Tiamuna kua tonoa hei laui mi nga mataa a te liotahitangi.

Page one of a four-page issue of Aotearoa, February 1, 1945. Source: Alexander Turnbull Library, Wellington. 
On the page above, obituaries run first, reflecting the tikanga of addressing the dead before turning to the business of the day (Rewi, 2010). The farewell for Wiki Tinihau Erueti, who had died in Kaihohe, addresses her directly, as is common in oratory, and exhorts her to "go to your parents, Mihi and Te Oka, and all the dead of the tribe". The story thanking a donor refers to his donation as huruhuru or feathers (money), referencing the whakatauki discussed earlier. The paper names the candidates vying for the Western Māori seat in a byelection made necessary as the incumbent had died in office. It then reports on the "biggest news of the week"; the Allies, here named Te Kotahitanga, are less than 50 miles from Berlin, where Hitara (Hitler) is facing defeat.

Although this iteration of Aotearoa lasted for five years, it was never a commercial success. The paper folded in until November 1945, two months after World War II ended (McCallum, 2013). Aotearoa was the last publication of its type - and, it appears, the end of a century of Māori-language general-interest newspapers. 


\section{References}

Anderson, A., Binney, J., \& Harris, A. (2014). Tangata whenua: An illustrated history. Bridget Williams Books.

Ballara, A. (1993). Wahine rangatira: Maori women of rank and their role in the women's kotahitanga movement of the 1890s. NZ Journal of History, 27(2), 127-139.

Beyond Russia. (2019, August 13). Debunked: There was no 'wolf truce' between Russia \& Germany during WW1. https://www.rbth.com/history/330804-there-was-nowolf-truce-russia-germany

Biggs, B. (1968). The Maori language past and present. In E. G. Schwimmer (Ed.), The Maori people in the nineteensixties: A symposium. Blackwood \& Janet Paul Ltd.

Curnow, J. (2002). A brief history of Māori-language newspapers. In Rere atu taku manu: Discovering history, language and politics in the Māori-language newspapers (pp. 17-41). Auckland University Press.

Curnow, J., Hopa, N., \& McRae, J. (2002). Rere atu, taku manu!: Discovering history, language and politics in the Māori-language newspapers. Auckland University Press.

Curnow, J., Hopa, N., \& McRae, J. (Eds.). (2006). He pitopito kōrero nō te perehi Māori: Readings from the Māorilanguage press. Auckland University Press.

Day, S. (2017, October 13). Get your macron on: A guide to writing te reo Māori the right way. The Spinoff. https://thespinoff.co.nz/atea/13-10-2017/get-yourmacron-on-a-guide-to-writing-maori-the-right-way/

Derby, M. (2014). Newspapers - first newspapers, 18391860. In Te Ara - The encyclopedia of New Zealand. Manatū Taonga Ministry for Culture and Heritage. http://www.TeAra.govt.nz/en/newspapers/page-1

Diamond, P. (2018). Savaged to suit: Māori and cartooning in New Zealand. New Zealand Cartoon Archive.

Hastings, D. (2013). Extra! Extra!: How the people made the news. Auckland University Press.

Head, L. (2002). Kupu pai, kupu kino: Good and bad words in Māori political writing. In Rere atu taku manu: Discovering history, language and politics in the Māori- 
language newspapers (pp. 134-152). Auckland University Press.

Hocken, T. M. (1909). A bibliography of the literature relating to New Zealand. J. Mackay.

Jones, A., \& Jenkins, K. (2011). Words between us: First Māori-Pākehā conversations on paper - He kōrero. Huia.

Ka'ai-Mahuta, R. (2011). The impact of colonisation on te reo Māori: A critical review of the state education system. Te Kaharoa, 4, 195-225. https://doi.org/10.24135/tekaharoa.v4i1.117

Kāretu, T. (2002). Māori print culture: The newspapers. In Rere atu taku manu: Discovering history, language and politics in the Māori-language newspapers (pp. 1-16). Auckland University Press.

Keegan. J. (2000). The First World War. Vintage.

King James Bible. (2017). King James Bible Online. https://www.kingjamesbibleonline.org (original work published 1769).

King, M. (2003). The Penguin history of New Zealand. Penguin Books.

Lascelles, P. (2014). Remembering seafarers: The (missing) history of New Zealanders employed in the mercantile marine during World War I. [Masters thesis, Massey University] https://mro.massey.ac.nz/handle/10179/5469

Linnell, J., Andersen, R., Andersone, Z., Balciauskas, L., Blanco, J., Boitani, L., Brainerd, S., Breitenmoser, U., Kojola, I., Liberg, O., Løe, J., Okarma, H., Pedersen, H., Promberger, C., Sand, H., Solberg, E., Valdmann, H., \& Wabakken, P. (2002). The fear of wolves: A review of wolf attacks on humans. NINA Oppdragsmelding, 731, 1-65. https://www.nina.no/archive/nina/PppBasePdf/oppdr agsmelding/731.pdf

Maslen, K., Harvey, R., \& Griffith, P. (1997). Book \& print in New Zealand: A guide to print culture in New Zealand. Victoria University Press.

McCallum, J. (2013). Rehutai Maihi. In Te Ara - The encyclopedia of New Zealand. Manatū Taonga Ministry for

Culture and

Heritage. 
http://www.TeAra.govt.nz/en/biographies/4m30/maihi -rehutai

McKay, R. A. (1940). A history of printing in New Zealand, 1830-1940. R. A. McKay for the Wellington Club of Printing House Craftsmen.

McRae, J. (1983). Maori manuscripts: Whose responsibility? Archifacts, 4.

McRae, J. (2002). E manu, tēnā koe! 'O bird, greetings to you': The oral tradition in newspaper writing. In $\mathrm{J}$. Curnow, N. Hopa, \& J. McRae (Eds.), Rere atu taku manu: Discovering history, language and politics in the Māorilanguage newspapers (pp. 42-59). Auckland University Press.

McRae, J. (2014). Māori newspapers and magazines - Ngā niupepa me ngā moheni. In Te Ara-The encyclopedia of New Zealand. Manatū Taonga Ministry for Culture and Heritage. https://teara.govt.nz/en/maori-newspapersand-magazines-nga-niupepa-me-nga-moheni/page-1

Mead, H., \& Grove, N. (2003). Ngā pēpeha a ngā tīpuna. Victoria University Press.

Mikaere, B., \& Head, L. (1988). Was nineteenth-century Maori society literate? Archifacts, 2, 17-20.

Moorfield, J., \& Johnston, L. (2004). Te reo Māori: Origins and development of the Māori language. In T. Ka'ai, J. Moorfield, M. Reilly, \& S. Mosley (Eds.), Ki te whaiao: An introduction to Māori culture and society (pp. 36-49). Pearson Education.

Niupepa: Māori Newspapers. (n.d.). Commentary Te hōkioi o Niu Tireni, e rere atu nā 1862-1863. http:/ / www.nzdl.org/gsdlmod?gg=text\&e=d-00000-00--off-0niupepa--00-0----0-10-0---0---0direct-10---4------0-11--11-en-50---20-about---00-0-1-00-0-0-11-1-0utfZz8-00-0-0-11-10-0utfZz-8-00\&a=p\&p=about

Orbell, M. (1996). The natural world of the Maori. David Bateman.

Parr, C. (1963). Māori literacy 1843-1867. Journal of the Polynesian Society, 72(3), 211-234. http://www.jps.auckland.ac.nz/document//Volume_72 
_1963/Volume_72\%2C_No._3/Maori_literacy_18431867\%2C_by_C._J._Parr\%2C_p_211_-_234/p1

Paterson, L. (2002). Kiri mā, kiri mangu: The terminology of race and civilisation in the mid-nineteenth-century Māori-language newspapers. In Rere atu taku manu: Discovering history, language and politics in the Mãorilanguage newspapers (pp. 78-97). Auckland University Press.

Paterson, L. (2004). Nga reo o nga niupepa: Māori language newspapers 1855-1863 [Doctoral thesis, University of Otago].

https://ourarchive.otago.ac.nz/handle/10523/146

Paterson, L. (2006). Colonial discourses: Niupepa Māori, 1855-1863. University of Otago Press.

Paterson, L. (2013). Te Hōkioi and the legitimization of the Māori nation. In The Fourth Eye: Mãori media in Aotearoa New Zealand (pp. 124-142). University of Minnesota Press.

Paterson, L. (2016). The New Zealand government's niupepa and their demise. New Zealand Journal of History, 50(2), 44-67.

http://www.nzjh.auckland.ac.nz/docs/2016/NZJH_50_ 2_03.pdf

Pool, I. (2015). Colonization and development in New Zealand between 1769 and 1900: The seeds of Rangiatea. Springer.

Reed, A. W., \& Calman, R. (2004). Reed book of Māori mythology. Reed Publishers.

Rewi, P. (2010). Whaikōrero: The world of Māori oratory. Auckland University Press.

Rogers, S. (1998). Crusoe among the Māori: Translation and colonial acculturation in Victorian New Zealand. Book History, 1, 182-195.

Royal, T. A. C. (Ed.). (2003) The woven universe: Selected writings of Rev. Maori Marsden. Estate of Rev. Maori Marsden, 2003.

Royal, T. A. C. (2017). Waikato tribes - the king movement. Te Ara - The encyclopedia of New Zealand. Manatū Taonga Ministry for Culture and Heritage. 
https://teara.govt.nz/en/photograph/1736/te-paki-omatariki

Scanlan, C. (2000). Birth of the inverted pyramid: A child of technology, commerce and history. In Reporting and writing: Basics for the 21st century (pp. 195-198). Oxford University Press.

Schudson, M. (2011). The sociology of news (2nd ed.). W. W. Norton \& Co.

Papers Past (n.d.). Te Paki o Matariki 1892-1935. https://paperspast.natlib.govt.nz/newspapers/paki-o$\underline{\text { matariki }}$

The Late Mr W. P. Snow. (1883, May 26). New Zealand Herald, 6.

Tilley, E., \& Cokley, J. (2008). Deconstructing the discourse of citizen journalism: Who says what and why it matters. Pacific Journalism Review, 14(1). https://doi.org/10.24135/pjr.v14i1.925

Walker, R. (2004). Ka whawhai tonu màtou: Struggle without end. Penguin.

Waymouth, L. (2002). Parliamentary representation for Māori: Debate and ideology in Te Wananga and Te Waka Maori o Niu Tirani, 1874-8. In Rere atu taku manu: Discovering history, language and politics in the Māorilanguage newspapers (pp. 153-173). Auckland University Press.

Weir, J. (1947). The press and society in New Zealand [Honours thesis, University of Canterbury]. https://ir.canterbury.ac.nz/handle/10092/5502.

Williams, D.V. (2001). Crown policy affecting Māori knowledge systems and cultural practices. Waitangi Tribunal.

Williams, H. W. (1971). A dictionary of the Māori language (7th ed.). Legislation Direct. 